\title{
Concentration of Salicylic Acid in Tomato Leaves after Foliar Aspersions of This Compound
}

\author{
Enrique Guzmán-Téllez ${ }^{1}$, Daniel Díaz Montenegro', Adalberto Benavides-Mendoza ${ }^{2 *}$ \\ ${ }^{1}$ Laboratorios Agroenzymas S.A. de C.V., Tlalnepantla, México \\ ${ }^{2}$ Departamento de Horticultura, Universidad Autónoma Agraria Antonio Narro, Saltillo, México \\ Email: ${ }^{*}$ abenmen@gmail.com
}

Received 29 April 2014; revised 29 May 2014; accepted 21 June 2014

Copyright (C) 2014 by authors and Scientific Research Publishing Inc. This work is licensed under the Creative Commons Attribution International License (CC BY). http://creativecommons.org/licenses/by/4.0/

\section{(c) (i) 0 pen Access}

\begin{abstract}
Increased plant tolerance to stress may be chemically induced with applications of salicylic acid (SA). The aim of this study was to determine the change in the SA leaf concentration over time in response to the SA spraying in leaves of greenhouse grown tomato. In sprayed leaves the SA concentration showed changes over time similar to the reported responses to environmental stress. Two days after the first application, the SA foliar concentration reached the maximum $\mathrm{of}^{8} \boldsymbol{\mu g} \cdot \mathrm{g}^{-1}$, equivalent to twice the amount observed in the control plants. SA decreased until it reached the level of control plants eight days later. A second application showed actually the same response, but with a faster decline of SA in two days. According to the results of this assay, SA applications on tomato should be performed within a minimum interval of eight days in order to maintain the SA concentration related with the increase in plant tolerance to environmental stress.
\end{abstract}

\section{Keywords}

Chemically Induced Resistance, Defense Signaling, Elicitor

\section{Introduction}

Plant hormones modify the growth and development of plants by inducing changes in cellular, physiological, and morphological processes [1] [2]. In recent years some new groups of hormones have been identified, and such is the case of salicylates, which are also involved in controlling plant growth and development. They also

${ }^{*}$ Corresponding author.

How to cite this paper: Guzmán-Téllez, E., Montenegro, D.D. and Benavides-Mendoza, A. (2014) Concentration of Salicylic Acid in Tomato Leaves after Foliar Aspersions of This Compound. American Journal of Plant Sciences, 5, 2048-2056. 
act as signals in the processes leading to plants' adaptive responses to environment. Salicylic acid is found naturally in plants, and it plays an important role in growth and stress tolerance [3]-[5], in addition to participation of the internal signals regulating the defensive response of plants against pests, pathogens [6] [7] and abiotic factors [4] [8]. When exogenously applied, SA induces stress tolerance, enhancing the plant's biological response against salinity and temperature extremes, in addition to modifying the antioxidants, nutrients, and chlorophyll concentrations [9] [10].

Taking into account the positive results found in several studies, the use of salicylates in agricultural practice seems to have possibilities from a commercial point of view [11]-[20]. Every day seems more obvious that the use of such compounds becomes a need, considering that current agricultural production standards demand a reduction of pesticide usage [21]. In a practical sense, the scientific literature and technical works made for the development and legal registration of products with active ingredients containing tolerance inducing compounds such as salicylic acid, describe the biological changes that occur in plants, for instance the activity adjustments of enzymes, antioxidants, and other metabolites [22]-[24] and changes in tolerance to environmental factors [20]. A lesser attention has received the residence time of the compound, as well as the behavior of the concentration of salicylates in plant tissues, and its residual effect as a result of a foliar application.

The objective of this study was to determine the change in the leaf salicylic acid concentration over time, in response to the SA spraying in leaves of greenhouse grown tomato (Solanum lycopersicum L.) under greenhouse conditions.

\section{Materials and Methods}

\subsection{Vegetative Material}

The study was carried out in Universidad Autónoma Agraria Antonio Narro, Saltillo, México, using tomato (Solanum lycopersicum L.) plants cv. Rio Grande (Petoseed). The seeds were sown on October 8, 2010, directly in polystyrene containers with $0.32 \mathrm{~L}$ substrate peat moss, TKB and agrolite 70:30 (v/v), placing 3 seeds per container. Ten days after germination a single seedling was preserved in each container. Fertilization was performed from 12 days after germination using Steiner solution at 25\% [25]. Initially, $30 \mathrm{~mL}$ of solution per seedling per day were applied, 30 days after germination the amount of nutrient solution was increased to $50 \mathrm{~mL}$ per seedling per day. Plants were grown under greenhouse conditions, with a maximum and minimum temperature range $12^{\circ} \mathrm{C}-32^{\circ} \mathrm{C}$.

\subsection{Description of Treatments}

The assay consisted of two treatments: salicylic acid (SA) and a control (distilled water). SA was reagent grade (CTR Scientific) at a concentration of $1 \times 10^{-4} \mathrm{M}\left(0.0138 \mathrm{~g} \cdot \mathrm{L}^{-1}\right)$. The first application was performed using a hand spray early in the day, applying the needed amount in order to achieve a full coverage of the leaves 30 days after germination (08 November 2010), once the seedlings showed the third true leaf. Twelve days after the first application of this compound a second one was made.

\subsection{Sampling of Plant Material}

The third developed leaf was taken as the organ to be evaluated. The first sampling of foliar material was made before the SA application to be able to conduct the evaluations and determine the initial concentration of SA in leaf tissue. The leaves were cut off from the plant, wrapped in aluminum foil and labeled before being, immediately, immersed in liquid nitrogen and be transferred to storage to a freezer at $-2.0^{\circ} \mathrm{C}$ in order to preserve them. After the SA application the previous operation was repeated every two days during a period of 22 days, taking the leaves of two plants per treatment every time. The sampling time was between 8:00 and 11:00 hours.

\subsection{Salicylic Acid Determination}

The process of analysis consisted of two phases: 1) preparation of the sample for extraction; 2) assaying of SA concentration in the obtained extract. For the preparation of the extraction samples the collected vegetative material was refrozen with liquid nitrogen for subsequent grinding and weighing of $0.05 \mathrm{~g}$ placing it in a $1.5 \mathrm{~mL}$ ependorf tube, adding $1 \mathrm{~mL}$ of the extraction solution (10\% methanol, $1 \%$ acetic acid, $89 \%$ distilled water) using 
for this purpose an automatic pipette (PRO Accumax 100 - $1000 \mu \mathrm{L}$ ). In order to get contact of the extraction solution and the total mass of the sample, the ependorf tube was put to vibration for 20 seconds on a vortex mixer (Scientific Products S. A.) and later on, in order to degas it, it was put for 5 minutes in a degasser (Bronsom S.A.) and then was centrifuged for 10 minutes at 10,000 $\mathrm{G}$ in a spectrofuge centrifuge (Labnet International, Inc.). After this process, translucent supernatant was recovered by a hand pipette to place it in a new labeled ependorf tube. A new amount of $0.5 \mathrm{~mL}$ of the extraction solution was added to each ependorf tube with the plant sample, in order to repeat the whole procedure, and remove again the translucent supernatant and add it to a new labeled ependorf tube obtaining, this way, an approximately $1.5 \mathrm{~mL}$ of solution, which was passed through spinning filters of $0.45 \mu \mathrm{m}$ (Millipore syrinx-driven filter unit). The SA assay was done on the filtering results using an LC Agilent chromatograph, model 1120 managed under EZChrom Elite Compact software, ver. 3.3.0B (Agilent 2005-2008 MR) under the following conditions: the cromatograph separation was performed in a Phenomenex Luna $\mathrm{C} 18100 \times 20 \mathrm{~mm}$ at $35^{\circ} \mathrm{C}$ column, with two solvent gradients $100 \%$ A $(94.9 \% \mathrm{H} 2 \mathrm{O}, 5 \%$ CH3CN, $0.1 \% \mathrm{CHOOH})$, to $100 \% \mathrm{~B}(5 \% \mathrm{H} 2 \mathrm{O}, 94.9 \% \mathrm{CH} 3 \mathrm{CN}, 0.1 \% \mathrm{CHOOH})$, using a detecting wavelength of $250 \mathrm{~nm}$ and a flow rate of $0.6 \mathrm{~mL} \mathrm{~min}{ }^{-1}$ for $10 \mathrm{~min}$. Solvent B was injected in the last minute, to later on inject again solvent $A$ to clean up the system and perform the subsequent injection for a new extraction solution. The injection of the extraction solution consisted of $20 \mu \mathrm{L}$. Each leaf sample was analyzed in duplicate. The results of SA obtained by the chromatograph in $\mathrm{mg} \cdot \mathrm{L}^{-1}$ were converted to $\mu \mathrm{g}$ of SA per gram of fresh weight.

\subsection{Determination of Root and Stems and Leaf Weight}

The root weight, and the weight of the stems and leaves, was determined taking, randomly, three plants per treatment. For the root, the substrate was removed with running water until the particles adhered were eliminated, and it was weighed in a grain balance. Once the fresh weight was obtained, the sample was dried at $60^{\circ} \mathrm{C}$ in a drying oven. As for the weight of stems and leaves the measuring was done directly on a triple beam balance (Ohaus, 2620 g).

\subsection{Experimental Design and Data Analysis}

A completely randomized experimental design was used, taking as the experimental unit one plant in one container, and taking two plants per treatment per evaluation for SA determination, and three plants for determination of root weight and stems and leaves weight per treatment per evaluation. Each treatment consisted of 80 replications. The data obtained were analyzed using analysis of variance, and mean's test using Tukey's test ( $\alpha=$ 0.05). The software used was SAS for Windows.

\section{Results}

\subsection{Change in the Concentration over Time of Salicylic Acid (SA) in Leaves}

After the exogenous SA application the concentration reached a peak two days after the application startup (DAAS) and then gradually decreased to a concentration statistically equal to that of the control plants 10 days after application (this data are shown in Figure 1). After the second application of exogenous SA at 14 DAAS, a similar response to the one obtained in the first application was observed. However, with the aim of increasing the information obtained after this second application leaf tissues were collected not allowing the two days to elapse. In order to achieve the data the sampling was made at 8, 14 and 24 hours after the application, finding a significant response at 24 hours (15 DAAS). After this, the response was almost the same described for the first application.

As far as it is concerned, the SA did not show a sensible variation in the control plants, except for the evaluation of the sixth DAAS where it showed a similar change to the one showed by the treated plants (this data are shown in Figure 1).

The second application made in this work showed a different result from the first one, since after reaching its SA peak accumulation it showed a faster decrease as compared to the first one (Figure 1).

\subsection{Change in Maximum Concentration of Salicylic Acid (SA)}

SA concentrations established in treated plants in this assay ranged from 3.0 to $8.27 \mu \mathrm{g} \cdot \mathrm{g}^{-1}$ fresh weight (Figure 
1), these values exceeded almost twice the ones observed in the control plants (whose concentrations ranged from 1.39 to $4.9 \mu \mathrm{g} \cdot \mathrm{g}^{-1}$ fresh weight).

\subsection{Plant Growth}

As far as stems and leaves growth is concerned, some differences were found at 4,12 and 15 DAAS (this data are shown in Figure 2), but values were similar at the end of the assay. In the absence of stress, the SA effect will depend on the concentration applied, and the plant species where the application is done, but sometimes no effect is found [9] [26].

\section{Discussion}

\subsection{Change in the Concentration over Time of Salicylic Acid (SA) in Leaves}

In sprayed leaves the SA concentration showed changes over time similar to the reported as responses to stress stimuli. This dynamic variation in the SA concentration in tomato leaves, induced by exogenous applications of this compound, is consistent with those reported by He et al. [27] when applying the red spider mite Tetrany

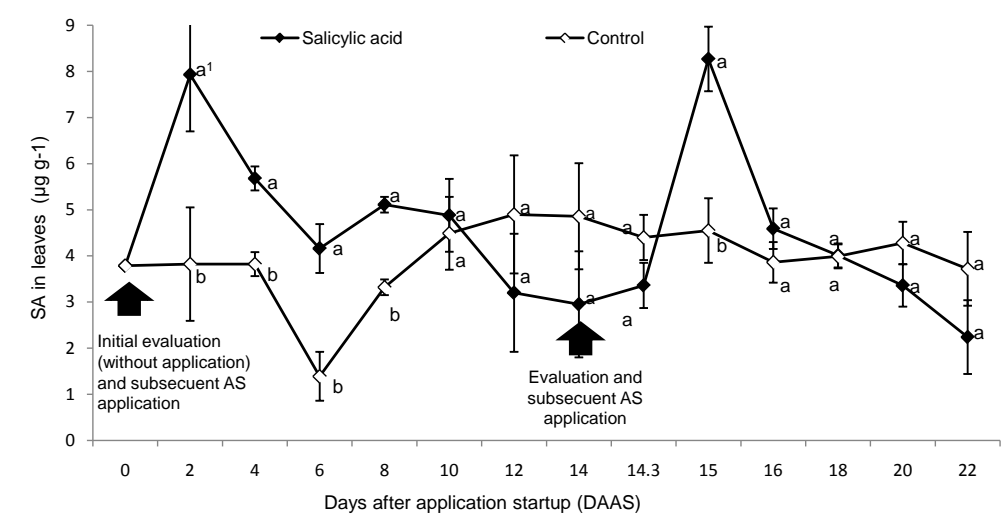

Figure 1. Concentration dynamics of SA in tomato (Solanum lycopersicum L.) leaves in response to its exogenous application at $10^{-4} \mathrm{M}\left(0.0138 \mathrm{~g} \cdot \mathrm{L}^{-1}\right)$. Mean comparison performed between the control and the treated one (SA application) every two days. Evaluation made every two days on the third fully expanded young leaf. Each point is an average of two plants, with two replications each, tested on Agilent 1120 LC chromatograph under EZCrom software. Means with the same letter are statistically equal (Tukey, $\alpha=0.05$ ).

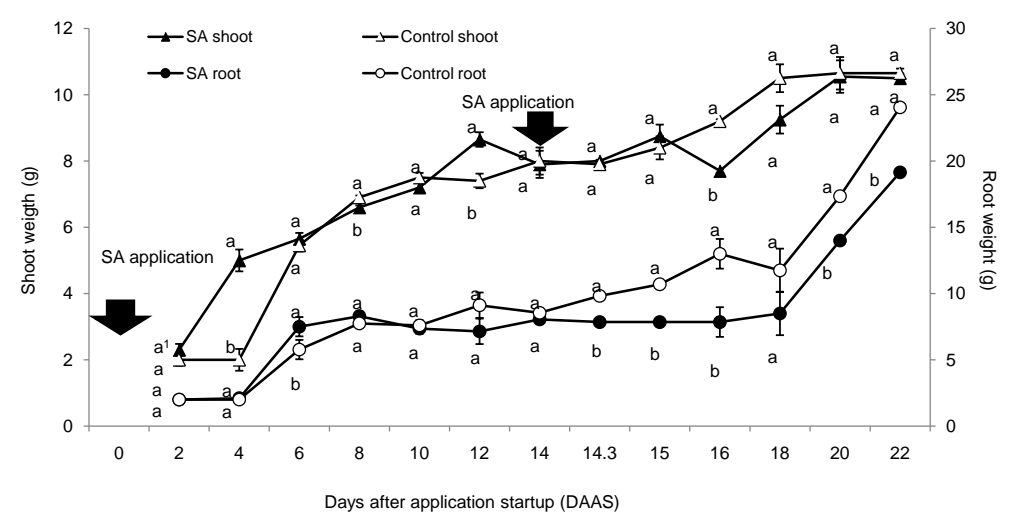

Figure 2. Growth of stem and leaves, and roots of tomato (Solanum lycopersicum L.) plants in response to foliar spraying with SA $1 \times 10^{-4} \mathrm{M}(0.0138$ $\mathrm{g} \cdot \mathrm{L}^{-1}$ ). Comparison of means between the control and the treated one (SA application) every two days. Each point is an average value of three plants. Means with the same letter are statistically equal (Tukey, $\alpha=0.05$ ). 
chus urticae (Koch) on bean leaves (Phaseolus vulgaris L.) and by Ogawa et al. [8] in Arabidopsis when applying mechanical stimuli on the leaves. The above-mentioned authors found significant increments in the concentration of foliar SA, with maximum peaks at 24 hours after stimulation, to later start a concentration decrease, with a maximum accumulation time similar to the one found in this study. This suggests a similarity in the temporal SA variation after an exogenous application and after a stress stimulus. Similarly, the inoculation of Fusarium equiseti in Arabidosis [28] and tobacco necrosis virus (TNV) [29], led to increments in the SA concentration in the leaves of seedlings. The peak SA concentration appeared 18 hours after the Fusarium inoculation and decreased on, while for TNV inoculation it showed up four days after inoculation, equaling the concentration of non inoculated plants eight days after inoculation, similarly to the observed in this assay. The described modification in SA concentration may vary depending on the organs being tested in a plant. For instance, if the inoculation of the virus occurs in the tobacco (Nicotiana tabacum L.) cotyledons, instead of a increase-decrease response in the SA concentration in the cotyledons at the time mentioned above, there is an steady rise during the different periods of evaluation. This phenomenon is accompanied, however, by the same behavior described for leaves, where the fall of the SA concentration appears after 48 hours [30]-[33].

Norman et al. [22] applied the SA in concentrations of 1.0, 0.1 and $0.01 \mathrm{mM}$ in tobacco cell cultures, making a subsequent measurement of the cytoplasmic concentration of the compound. The authors found out that even in this situation, the SA showed a high concentration in cells for up to 24 hours when applying $1.0 \mathrm{mM}$, whereas for concentrations of 0.1 and $0.01 \mathrm{mM}$ the permanence time of the compound in the cells was only one hour. The presence of high SA concentrations in leaves subjected to biotic or abiotic stress is attributed to its role as a signaling compound in the induction of acquired systemic resistance [21] [33] [34]. In the absence of an evident stress to induce the SA synthesis, and in the presence of exogenous SA applications made in this work, the observed concentrations could be attributed to the balance between the residual life and the transformation, or degradation, of applied SA. It is assumed that the cellular SA concentration must be kept within certain limits, at an appropriate level to maintain cellular redox homeostasis, according to the needs imposed by the environment, particularly by irradiance [35] as well as by SA interaction with other cellular activities [36].

The rapid change in the detectable SA amount, after the peak concentration, seems to be partially due to the SA transformation into its conjugated forms [27] [37] [38] mainly as glycosides of salicylic and benzoic acid, methylated forms, or species activated with coenzyme A [39]. Meanwhile Mustafa et al. [40] found out in $\mathrm{Ca}$ tharantus roseus (L.) cell cultures, that the SA applied to the medium, and absorbed by the cells, was metabolized into 2,5-hydroxybenzoic glucoside. The same happens in Arabidopsis thaliana under mechanical stress [8] where O- $\beta$-D-glucosyl benzoic acid is accumulated in nearly twice the amount found in SA, i.e. 3 to $7 \mathrm{mM}$. Once the SA changes into its conjugated form it is supposed to form a kind of reserve that, if necessary, can be converted back to SA [39]. Panina et al. [41] observed the transformation of SA conjugates in free SA within 48 h. in potato disks infected with Phytophthora infestans.

The possible reason why the SA concentration decreased more rapidly after the second application, as compared to the first one, is due to the fact that stress response induced systems are very responsive to the presence of the inducing compound or compounds, but a second or third application made shortly after the first one usually saturates the response [42]. One might think that this is the situation observed in the second application, and that as the response saturation increases, more rapidly is metabolized the SA in plant tissues.

Salicylic acid has natural concentration variations arising out of development events such as different phenological stages, and flowering [43]. It is also known that constant adjustments take place in the SA concentration depending on the conditions of temperature and irradiance [35]. Thus, the behavior displayed by the control plants, in terms of variations in the foliar SA concentration, can be assumed to be normal.

\subsection{Change in Maximum Concentration of Salicylic Acid (SA)}

The maximum values found after application (at two and 15-DAAS) are similar to those reported by He et al. [27] on bean leaves 24 hours after stimulation with the spider mite Tetranichus urticae Koch. In this case, the presence of mites gave place to a maximum concentration of $12 \mu \mathrm{g} \cdot \mathrm{g}^{-1} \mathrm{SA}$ of fresh weight, a value that exceeds the obtained with an exogenous SA application as a foliar spray. With another biological model, the infection with tobacco mosaic virus (TMV), Enyedi et al. [30] found out that infected cells reached 3.5 to $6.0 \mu \mathrm{g} \cdot \mathrm{g}^{-1} 144$ hours after SA application in the culture medium in concentrations of 25 and $100 \mu \mathrm{M}$ SA. In the same way, Malamy et al. [44] found an increase of $3 \mu \mathrm{g} \cdot \mathrm{g}^{-1}$ at 60 hours after putting tobacco plants under high temperatures, 
while Shulaev et al. [31] assayed maximum SA concentrations in TMV infected tobacco, equivalent to $10 \mu \mathrm{g} \cdot \mathrm{g}^{-1}$ fresh weight, increasing the concentration as the sample approached the site of infection (144 hours after it). On the other hand, Barbaus and Jacobsen [45], when applying $50 \mathrm{mg} \cdot \mathrm{L}^{-1}$ probenazole (a compound used in agricultural practice for their ability to induce tolerance) in sugar beet (Beta vulgaris L.), found the highest SA concentration in $3.1 \mu \mathrm{g} \cdot \mathrm{g}^{-1}$ fresh weight. Iwai et al. [46], applying the same compound on rice plants, found $1.5 \mu \mathrm{g} \cdot \mathrm{g}^{-1}$ fresh weight, at the time of the highest accumulation. It is clear that the endogenous SA concentration values depend on the type of test applied, and the conditions under which it takes place, remain a constant partial transformation of the free SA into its conjugated forms, even if the response shows very high SA concentrations, and time responses as short as 30 minutes [22].

Even those studies reporting lower SA concentrations, as the ones obtained by Park et al. [33] and Yalpani et al. [38] in the order of $0.35 \mu \mathrm{g} \cdot \mathrm{g}^{-1}$ fresh weight, 144 hours after infecting the plants with TMV, showed the same response described above of SA increments in the concentration, and of a subsequent decline, presumably to incorporate into conjugated chemical species.

\subsection{Plant Growth}

Generally speaking, the use of SA as a foliar spray shows a benefit on the growth of the aerial parts of plants in situations where some stressors are present [12] [18] [20] [47]. In the case of root weight no significant difference was found after the first SA spraying, however, after the second application a lower root growth in the treated plants was observed. Most of the literature indicated that SA effect on root growth is positive [10] [11] [13] [48] [49], but in some studies like in Lian et al. [26] negative effects were found in root biomass in some of the applied concentrations. The authors indicated, as a probable explanation of the results, an increased derivation of the energy estimates of root defense responses induced by SA.

\section{Conclusions}

Concentration of SA, resulting of a foliar application, showed a response of accumulation and subsequent concentration decline similar to the one observed by induction under stress conditions. The response was consistent across two foliar spray events.

Salicylic acid applied as a foliar spraying increased the foliar concentration of the compound to $8 \mu \mathrm{g} \cdot \mathrm{g}^{-1} \mathrm{fresh}$ weight as compared with the control that showed a maximum value of $5 \mu \mathrm{g} \cdot \mathrm{g}^{-1}$.

According to the results of this assay, SA applications on tomato should be performed within a minimum interval of eight days in order to maintain the SA concentration related with the increase in plant tolerance to environmental stress.

\section{References}

[1] Browse, J. (2009) Jasmonate Passes Muster: A Receptor and Targets for the Defense Hormone. Annual Review of Plant Biology, 60, 183-205. http://dx.doi.org/10.1146/annurev.arplant.043008.092007

[2] Ashraf, M., Akram, N.A., Arteca R.N. and Foolad, M.R. (2010) The Physiological, Biochemical and Molecular Roles of Brassinosteroids and Salicylic Acid in Plant Processes and Salt Tolerance. Critical Reviews in Plant Sciences, 29, 162-190. http://dx.doi.org/10.1080/07352689.2010.483580

[3] Noreen, S., Ashraf, M., Hussain, M. and Jamil, A. (2009) Exogenous Application of Salicylic Acid Enhances Antioxidative Capacity in Salt Stressed Sunflower (Helianthus annus L.) Plants. Pakistan Journal of Botany, 41, 473-479.

[4] Khan, N.A., Syeed, S., Masood, N., Nazar, R. and Iqbal, N. (2010) Application of Salicylic Acid Increases Contents of Nutrients and Antioxidative Metabolism in Mungbean and Alleviates Adverse Effects of Salinity Stress. International Journal of Plant Biology, 1, e1.

http://web.b.ebscohost.com/ehost/pdfviewer/pdfviewer?sid=2f426a81-8cf2-4521-9fbe-9a207ab70a10\%40sessionmgr1 $\underline{12 \& \text { vid=1\&hid=127 }}$

[5] Purcarea, C. and Cachiţă-Cosma, D. (2010) Studies Regarding the Effects of Salicylic Acid in Maize (Zea mays L.) Seedling under Salt Stress. Studia Universitatis “Vasile Goldiş”, Seria Ştiinţele Vieţii, 20, 63-68.

[6] Girling, R.D., Madison, R., Hassall, M., Poppy, G.M. and Turner, J.G. (2008) Investigation into Plant Biochemical Wound-Responses Pathways Involved in the Production of Aphid-Induced Plant Volatiles. Journal of Experimental Botany, 59, 3077-3085. http://dx.doi.org/10.1093/jxb/ern163

[7] Zhang, Z., Li, Z., Staswick, E., Wang, M., Zhu, Y. and He, Z. (2009) Dual Regulation Role of GH3.5 in Salicylic Acid 
and Auxin during Arabidopsis-Pseudomonas siringae Interaction. Plant Physiology, 145, 450-464. http://dx.doi.org/10.1104/pp.107.106021

[8] Ogawa, T., Ara, T., Aoki, K., Suzuki, H. and Shibata, D. (2010) Transient Increase in Salicylic Acid and Its Glucose Conjugates after Wounding in Arabidopsis Leaves. Plant Biotechnology, 27, 205-209. http://dx.doi.org/10.5511/plantbiotechnology.27.205

[9] Benavides, A., Salazar, A., Ramírez, F., Robledo, V., Ramírez, H. and Maiti, R. (2004) Tratamiento de semilla de chile con ácido salicílico y sulfosalicílico y respuesta de las plántulas al frío. Terra Latinoamericana, 22, 41-47.

[10] Noreen, S. and Ashraf, M. (2008) Alleviation of Adverse Effects of Salt Stress on Sunflower (Helianthus annuus L.) by Exogenous Application of Salicylic Acid: Growth and Photosynthesis. Pakistan Journal of Botany, 40, 1657-1663.

[11] Ahmad, I., Basra, S.M.A., Afzal, I., Farooq, M. and Wahid, A. (2013) Growth Improvement in Spring Maize through Exogenous Application of Ascorbic Acid, Salicylic Acid and Hydrogen Peroxide. International Journal of Agriculture and Biology, 15, 95-100.

[12] Khodary, S. (2004) Effect of Salicylic Acid on Growth, Photosynthesis and Carbohydrate Metabolism in Salt-Stressed Maize Plants. International Journal of Agriculture and Biology, 6, 5-8.

[13] Gemes, K., Poor, P., Sulyok, Z., Szepesi, A., Szabo, M. and Tari, I. (2008) Role of Salicylic Acid Pre-Treatment on the Photosynthetic Performance of Tomato Plants (Lycopersicum sculentum Mill. L. cv. Rio Fuego) under Salt Stress. Acta Biologica Szegediensis, 52, 161-162.

[14] Azooz, M.M. (2009) Salt Stress Mitigation by Seed Priming with Salicylic Acid in Two Faba Bean Genotypes Differing in Salt Tolerance. International Journal of Agriculture and Biology, 11, 343-350.

[15] Noreen, S. and Ashraf, M. (2009) Assessment of Variation in Antioxidative Defense System in Salt-Treated Pea (Pisum sativum) Cultivars and Its Putative Use as Salinity Tolerant Markers. Journal of Plant Physiology, 166, 17641774. http://dx.doi.org/10.1016/j.jplph.2009.05.005

[16] El-Khallal, S.M., Hathout, A., Ahsour, A. and Kerrit, A. (2009) Brassinolide and Salicylic Acid Induced Antioxidant Enzymes, Hormonal Balance and Protein Profile of Maize Plants Grown under Salt Stress. Research Journal of Agriculture and Biological Sciences, 5, 391-402.

[17] Jabbarzadeh, J., Khosh, K.M. and Salehi, H. (2009) The Effect of Foliar Applied Salicylic Acid on Flowering of African Violet. Australian Journal of Basic and Applied Sciences, 3, 4693-4696.

[18] Najafian, S., Khoshkhui, M., Tavallali, V. and Saharkhiz, M.J. (2009) Effect of Salicylic Acid and Salinity in Thyme (Thymus vulgaris L.): Investigation on Changes in Gas Exchange, Water Relations, and Membrane Stabilization and Biomass Accumulation. Australian Journal of Basic and Applied Sciences, 3, 2620-2626.

[19] Villanueva, E., Alcantar, G., Sánchez, P., Soria, M. and Larque, A. (2009) Efecto del ácido salicílico y dimetilsulfoxido en floración de Crisantemum morifolium (Ramat) Kitamura en Yucatán. Revista Chapingo, Serie Horticultura, 15, 25-31.

[20] Azooz, M. and Youseef, M. (2010) Evaluation of Heat Shock and Salicylic Acid Treatments as Inducers of Drought Stress Tolerance in Wheat. American Journal of Plant Physiology, 5, 56-70. http://dx.doi.org/10.3923/ajpp.2010.56.70

[21] Esmailzadeth, M., Soleimani, M.J. and Rouhani, H. (2008) Exogenous Application of Salicylic Acid for Induced Systemic Acquired Resistance against Tomato Steam Canker Disease. Journal of Biological Sciences, 8, 1039-1044. http://dx.doi.org/10.3923/jbs.2008.1039.1044

[22] Norman, C., Howell, K.A., Millar, A.H., Whelan, J.M. and Day, D.A. (2004) Salicylic Acid Is an Uncoupler and Inhibitor of Mitochondrial Electron Transport. Plant Physiology, 134, 492-501. http://dx.doi.org/10.1104/pp.103.031039

[23] Kaydan, D., Yagmur, M. and Okut, N. (2006) Effects of Salicylic Acid on the Growth and Some Physiological Characters in Salt Stressed Wheat (Triticum aestivum L.). Tarim Bilimleri Dergisi, 13, 114-119.

[24] Khalili, M., Hasanloo, T., Kasemi, T.S.K. and Sepehrifar, R. (2010) Effect of Salicylic Acid on Antioxidant Activity in Milk Thistle Haired Root Cultures. Journal of Medicinal Plants, 35, 51-61.

[25] Steiner, A.A. (1961) A Universal Method for Preparing Nutrient Solutions of a Certain Desired Composition. Plant and Soil, 15, 134-154. http://dx.doi.org/10.1007/BF01347224

[26] Lian, B., Zhou, X., Miransari, M. and Smith, D.L. (2000) Effects of Salicylic Acid on the Development and Root Nodulation of Soybean Seedling. Journal of Agronomy and Crop Science, 185, 187-192. http://dx.doi.org/10.1046/j.1439-037x.2000.00419.x

[27] He, W., Li, H., Li, X., Li, M.Q. and Chen, Y.W. (2007) Tetranynchus urticae Koch Induced Accumulation of Salicylic Acid in Frijole Leaves. Pesticide Biochemistry and Physiology, 88, 78-81. http://dx.doi.org/10.1016/j.pestbp.2006.09.002

[28] Kojima, H., Hossain, M.M., Kubota, M. and Hyakumachi, M. (2013) Involvement of the Salicylic Acid Signaling Pathway in the Systemic Resistance Induced in Arabidopsis by Plant Growth-Promoting Fungus Fusarium equiseti 
GF19-1. Journal of Oleo Science, 62, 415-426. http://dx.doi.org/10.5650/jos.62.415

[29] Molders, W., Buchala, A. and Metraux, J.P. (1996) Transport of Salicylic Acid in Tobacco Necrosis Virus Infected Cucumber Plants. Plant Physiology, 112, 787-792.

[30] Enyedi, A.J., Nalpai, N., Silverman, P. and Raskin, I. (1992) Localization, Conjugation, and Function of Salicylic Acid on Tobacco during Hypersensitive Reaction to Tobacco Mosaic Virus. Proceedings of the National Academy of Sciences of the United States of America, 89, 2480-2484. http://dx.doi.org/10.1073/pnas.89.6.2480

[31] Shulaev, V., León, J. and Raskin, I. (1995) Is Salicylic Acid a Translocated Signal of Systemic Acquired Resistance in Tobacco? The Plant Cell, 7, 1691-1701. http://dx.doi.org/10.1105/tpc.7.10.1691

[32] Seskar, M., Shulaev, V. and Raskin, I. (1998) Endogenous Methyl Salicylate in Pathogen-Inoculated Tobacco Plants. Plant Physiology, 116, 387-392. http://dx.doi.org/10.1104/pp.116.1.387

[33] Park, S.W., Kaimoyo, E., Kumar, D., Mosher, S. and Klessig, D.F. (2007) Methyl Salicylate Is a Critical Mobile Signal for Plant Systemic Acquired Resistance. Science, 318, 113-116. http://dx.doi.org/10.1126/science.1147113

[34] Prithiviraj, B., Bais, H.P., Weir, T., Suresh, B., Najarro, E.H., Dayacar, B.V., Swheizer, H.P. and Vivanco, J.M. (2005) Down Regulation of Virulence Factors of Pseudomonas aeruginosa by Salicylic Acid Attenuates Its Virulence on Arabidopsis thaliana and Caenobhabditis elegans. Infection and Immunity, 73, 5319-5328. http://dx.doi.org/10.1128/IAI.73.9.5319-5328.2005

[35] Mateo, A., Funck, D., Mühlenbock, P., Kular, B., Mullineaux, P.M. and Karpinski, S. (2006) Controlled Levels of Salicylic Acid Are Required for Optimal Photosynthesis and Redox Homeostasis. Journal of Experimental Botany, 57, 1795-1807. http://dx.doi.org/10.1093/jxb/erj196

[36] Genoud, T., Bachala, A.J., Chua, N.H. and Metraux, J.P. (2002) Phytochrome Signaling Modulates the SA-Perceptive Pathway in Arabidopsis. The Plant Journal, 31, 87-95. http://dx.doi.org/10.1046/j.1365-313X.2002.01338.x

[37] Klämbt, H.D. (1962) Conversion in Plants of Benzoic Acid to Salicylic Acid and Its $\beta d$-Glucoside. Nature, $196,491$. http://dx.doi.org/10.1038/196491a0

[38] Yalpani, N., Silverman, P., Wilson, A., Kleier, D. and Raskin, I. (1991) Salicylic Acid Is a Systemic Signal and an Inducer of Pathogenesis Related Protein in Virus Infected Tobacco. The Plant Cell, 3, 809-818. http://dx.doi.org/10.1105/tpc.3.8.809

[39] Wildermut, M.C., Dewdney, J., Wu, G. and Ausubel, F.M. (2001) Isochorismathe Synthase Is Required to Synthesize Salicylic Acid for Plant Defence. Nature, 414, 562-565. http://dx.doi.org/10.1038/35107108

[40] Mustafa, N.R., Kin, H.K., Choi, Y.H. and Vepoorte, R. (2009) Metabolic Changes of Salicylic Acid-Elicited Catharanthus roseus Cell Suspension Cultures Monitored by NMR-Based Metabolomics. Biotechnology Letters, 31, 19671974. http://dx.doi.org/10.1007/s10529-009-0107-1

[41] Panina, Y.S., Gerasimova, N.G., Chalenco, G.I., Vasyukova, N.I. and Ozeretskovskaya, O.L. (2005) Salicylic Acid and Phenylalanine Ammonia-Lyase in Potato Plants Infected with the Causal Agent of Late Blight. Russian Journal of Plant Physiology, 52, 511-515. http://dx.doi.org/10.1007/s11183-005-0075-9

[42] Tao, Y., Xie, Z., Chen, W., Glazebrook, J., Chang, H.S., Han, R., Zhu, T., Zou, G. and Katagiri, F. (2003) Quantitative Nature of Arabidopsis Responses during Compatible and Incompatible Interactions with the Bacterial Pathogen Pseudomonas syringae. The Plant Cell, 15, 317-330. http://dx.doi.org/10.1105/tpc.007591

[43] Abreu, M.E. and Munne, B.S. (2009) Salicylic Acid Deficiency NahG Transgenic Lines and sid2 Mutants Increases Seed Yield in the Annual Plant Arabidopsis thaliana. Journal of Experimental Botany, 60, 1261-1271. http://dx.doi.org/10.1093/jxb/ern363

[44] Malamy, J., Henning, J. and Klessig, D.F. (1992) Temperature-Dependent Induction of Salicylic Acid and Its Conjugates during the Resistance Response to Tobacco Mosaic Virus Infection. The Plant Cell, 4, 359-366. http://dx.doi.org/10.1105/tpc.4.3.359

[45] Barbaus, R.L. and Jacobsen, B.J. (2007) Biocontrol Elicited Systemic Resistance in Sugarbeet Is Salicylic Acid Independent and NPR1 Dependent. Journal of Sugar Beet Research, 44, 17-35. http://dx.doi.org/10.5274/jsbr.44.1.17

[46] Iwai, T., Seo, S., Mitsuhara, I. and Ohashi, K. (2007) Probenazole Induced Accumulation of Salicylic Acid Confers Resistance to Magnaporte griseain Adults Plants Rice. Plant and Cell Physiology, 48, 915-924. http://dx.doi.org/10.1093/pcp/pcm062

[47] Wang, L.J., Fan, L., Loescher, W., Duan, G.J., Cheng, J.S., Luo, H.B. and Li, S.H. (2010) Salicylic Acid Alleviates Decreases in Photosynthesis under Heat Stress and Accelerates Recovery in Grapevine Leaves. BMC Plant Biology, 10, 34.

[48] Tuna, L., Kaya, C., Dikilitas, M., Yokas, I., Burum, B. and Altulnu, H. (2007) Comparative Effect of Various Salicylic Acid Derivates on Key Growth Parameters and Some Enzyme Activities in Salinity Stressed Maize (Zea mays L.) Plants. Pakistan Journal of Botany, 39, 787-798. 
[49] Umebese, C.T., Olatimilehin, T.O. and Ogunsusi, T.A. (2009) Salicylic Acid Protects Nitrate Reductase Activity, Growth and Proline in Amaranth and Tomato Plants during Water Deficit. American Journal of Agricultural and Biological Sciences, 4, 224-229. http://dx.doi.org/10.3844/ajabssp.2009.224.229 
Scientific Research Publishing (SCIRP) is one of the largest Open Access journal publishers. It is currently publishing more than 200 open access, online, peer-reviewed journals covering a wide range of academic disciplines. SCIRP serves the worldwide academic communities and contributes to the progress and application of science with its publication.

Other selected journals from SCIRP are listed as below. Submit your manuscript to us via either submit@scirp.org or Online Submission Portal.
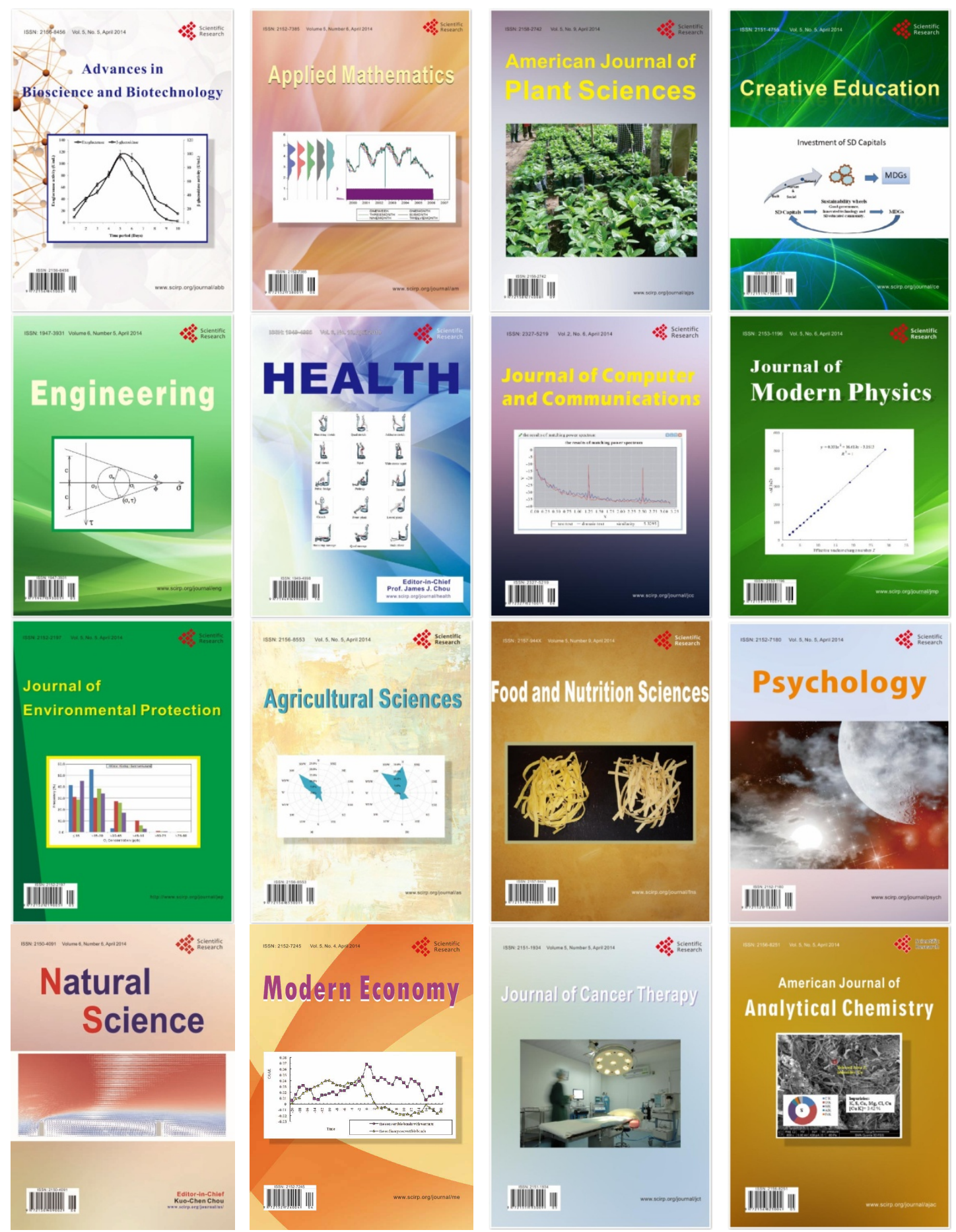